www.jmscr.igmpublication.org

Impact Factor (SJIF): 6.379

Index Copernicus Value: 71.58

ISSN (e)-2347-176x ISSN (p) 2455-0450

crossref DOI: _https://dx.doi.org/10.18535/jmscr/v6i4.135

Journal Of Medical Science And Clinical Research

\title{
Clinical outcome of Radical Chemoradiation in Squamous cell carcinoma of the Esophagus
}

\author{
Authors \\ Dr Arun Sankar Sudha, MD, Dr Sivanandan C D, Dr Sajeed A, Dr Roshni Shyam, \\ Dr Geethi M H, Dr Lijeesh A L, Dr Nithyaanandan Natarajan \\ Division of Radiation oncology, Regional Cancer Centre, Thiruvananthapuram, Kerala, India \\ Corresponding Author \\ Dr Arun Sankar Sudha MD \\ Division of Radiation oncology, Regional Cancer Centre, Thiruvananthapuram, Kerala, India, \\ Email:drarunssankar@gmail.com,arunsank@gmail.com, Phone: +91-9249554405
}

\begin{abstract}
Aim \& Objective: Radical chemoradiation is one of the options for curative treatment of carcinoma of the esophagus. This study reports the institutional experience with radical chemoradiation in patients with squamous cell carcinoma of the esophagus

Patients \& Methods: Patients with non-metastatic squamous cell carcinoma of the esophagus registered between 2013 and 2015 at the hospital were evaluated for retrospective study. The patients were treated with radiation doses of 50-60 Gy by conformal techniques and concurrent platinum, 5-fluorouracil based chemotherapy.

Results: Sixty nine patients were found eligible for the study. The mean age was 60 years and had $76.8 \%$ males. Thirty six (52.2\%) patients had cT4 disease, and $26(37.7 \%)$ had cN+disease. All patients received radical radiotherapy, while $90 \%$ received chemotherapy. Twenty eight (40.6\%) patients developed recurrence, with primary site being the most common site of failure. The median time to recurrence was 17 months (range: 0-40months). The median overall survival was 43 months and disease free survival was 40 months. The 2 and 3 year overall survival was $72.6 \%$ and $54.4 \%$ and disease free survival was $62 \%$ and $53.8 \%$ respectively.

Conclusion: Radical chemoradiation for squamous cell carcinoma of esophagus is feasible in the real-life setting and provides a good 3 year overall survival of 54\%. More accurate staging of disease with endoscopic ultrasound and PET-CT, more sophisticated radiation with potential to reduce organ toxicity and dose-escalation, and reliable assessment of response to treatment with PET-CT and endoscopic ultrasound with early salvage treatment has the potential to improve these survival figures.

Keywords: Esophageal neoplasms, Chemoradiotherapy, Squamous cell carcinoma.
\end{abstract}

\section{Introduction}

Oesophageal cancer is the eighth most common cancer worldwide, and the sixth most common cause of death from cancer. In India, it is the seventh most common cancer with an estimated incidence of 41800 cases $^{(1)}$. For squamous cell carcinoma of the esophagus, radical chemoradiation and neoadjuvant chemoradiation 
followed by surgery are considered standard treatment options. While some retrospective studies and National database searches have reported better survival with triple modality, 2 randomised studies and the Cochrane Database systematic review have reported similar overall survival, with a differing pattern of recurrence ${ }^{(2-7)}$. For patients who are not candidates for surgery either due to locally advanced nature of disease or other medical reasons, radical chemoradiation is the treatment of choice. This study reports on the institutional experience with radical chemoradiation in squamous cell carcinoma of the esophagus.

\section{Patients and Methods}

Patients with non-metastatic squamous cell carcinoma of the esophagus registered between 2013 and 2015 at the hospital were evaluated for this study. Eligibility criteria included age $<75$ yrs, cT3 or T4 or N1 lesions, with normal baseline renal, liver function and who received radical dose of radiation with concurrent chemotherapy. Patients with trachea-esophageal fistula were excluded.

\section{Treatment}

For radiation, patients underwent CT simulation with oral and IV contrast. Gross tumor volume (GTV) was contoured on the planning CT with information from all available investigations, including endoscopy finding $\mathrm{s}$ and diagnostic $\mathrm{CT}$ findings. PET-CT was not routinely done. Clinical target volume (CTV) was drawn by expanding the GTV $1 \mathrm{~cm}$ laterally and $3 \mathrm{~cm}$ superiorly and inferiorly, while respecting anatomic barriers. The CTV was expanded uniformly by $1 \mathrm{~cm}$ to generate the PTV. The radiation was planned in Eclipse (Varian Medical Systems, USA)by 3D conformal technique. The radiation dose was either 50 to $50.4 \mathrm{~Gy}$ in 25 to 28 sessions at 2 to $1.8 \mathrm{~Gy} /$ day or $60 \mathrm{~Gy}$ in 30 sessions at $2 \mathrm{~Gy} / \mathrm{day}$ according to physician's preference.

Chemotherapy consisted of a platinum either Cisplatin at $80 \mathrm{mg} / \mathrm{m}^{2}$ or Carboplatin at AUC-5 along with 5 -Fluorouracil at $1000 \mathrm{mg} / \mathrm{m}^{2} /$ day on days 1-4, repeated every 4 weeks for 4 cycles. Most patients received one cycle of chemotherapy prior to radiation, 2 cycles concurrent with and one cycle as adjuvant chemotherapy. Patients over 70 years received weekly doses of Cisplatin at $50 \mathrm{mg} / \mathrm{m}^{2}$ or Carboplatin at AUC-2.

Post treatment patients were followed up every 34 monthly with clinical examination and barium swallow. Endoscopy and CT scans were done where clinically indicated. Recurrences were classified as local if at the primary site, nodal whether in the irradiated or unirradiated regional nodes, and distant metastasis.

\section{Statistical Analysis}

Survival analysis and actuarial probabilities were calculated with the Kaplan Meier test and the log rank test used for performing univariate analysis for factors predictive of local control and disease free survival. Cox proportional hazards model was used for multivariate analysis. All $\mathrm{P}$ values were two sided and a $\mathrm{P}$ value less than 0.05 were taken as significant. Patients who had recurrent disease, if they are lost to follow-up, they are taken as dead as on the last date of follow-up.

\section{Results}

We identified 69 patients registered between 2013 and 2015, who could be included in this study, with a median follow-up of 26 months (range 358months). For the living patients, the median follow-up was 31.5 months. The mean age of the patients was 60 years, $53(77 \%)$ being males, 36 (52\%) had T4 disease and 26(37.7\%) had nodal metastasis at diagnosis (Table 1).

The one year disease free survival (DFS) and overall survival (OS) was $83 \%$ and $93.7 \%$ respectively. The 2 and 3 year overall survival was $72.6 \%$ and $54.4 \%$ and disease free survival was $62 \%$ and $53.8 \%$ respectively. The median overall survival was 43 months and disease free survival was 40 months. The loco-regional disease free survival at 2 and 3 year was $71.3 \%$ and $65.9 \%$ respectively. 


\section{JMSCR Vol||06||Issue||04||Page 804-812||April}

\section{Patterns of recurrence}

Twenty eight (40.6\%) patients developed recurrence of disease. Twelve (17.4\%) and 7 $(10 \%)$ patients had primary site and regional nodes respectively as their first site of recurrence, while $9(13 \%)$ had distant metastasis. Most of the recurrences $(82 \%)$ occurred within the first 2 years (range 0-40 months). Recurrence at the primary site is rare after 2 years $(8.3 \%)$, however $28.6 \%$ of nodal recurrence occurred after 2 years (table 2).

Predictors of disease free survival and overall survival

In univariate analysis, none of the various factors tested were predictive for disease free survival or overall survival (tables $3 \& 4$ ).

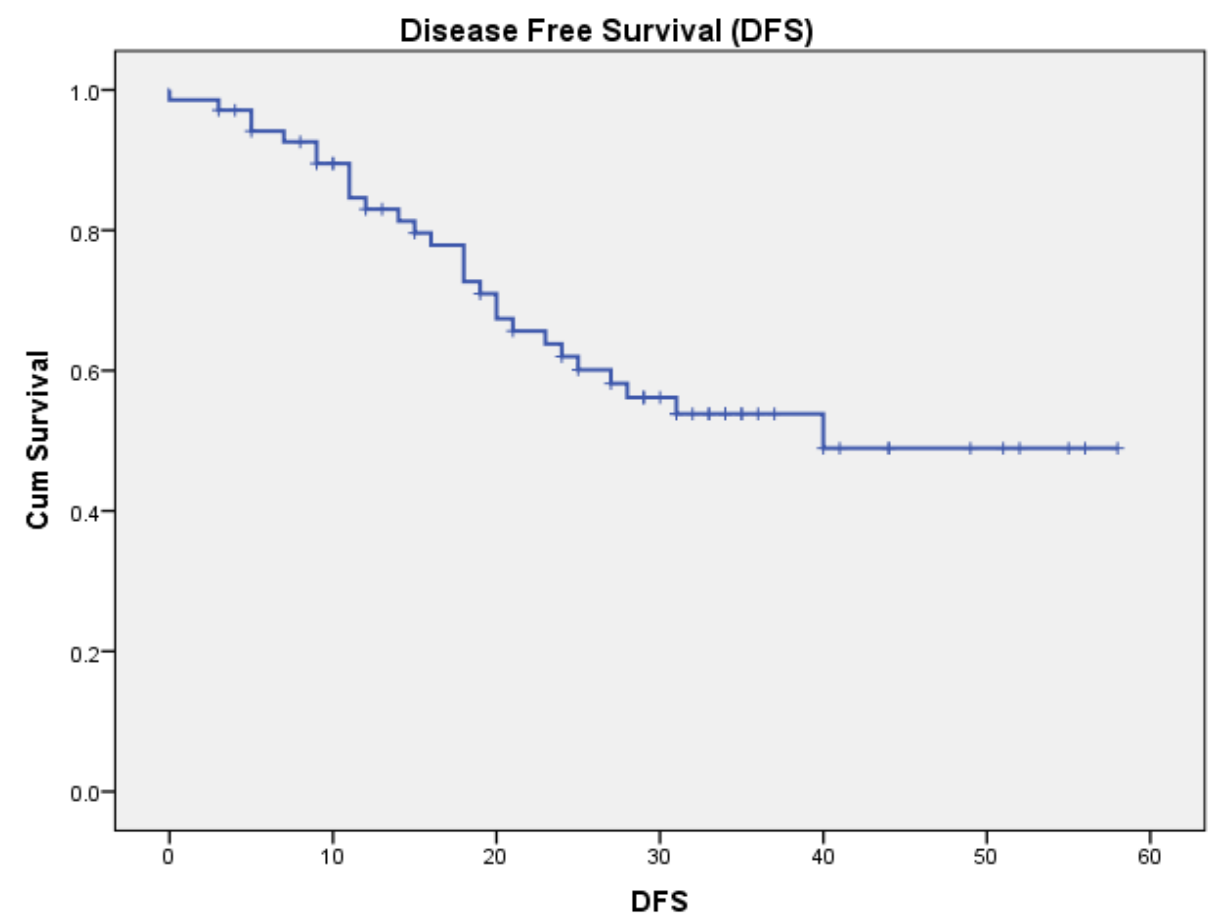

Figure 1: Disease Free Survival (DFS)

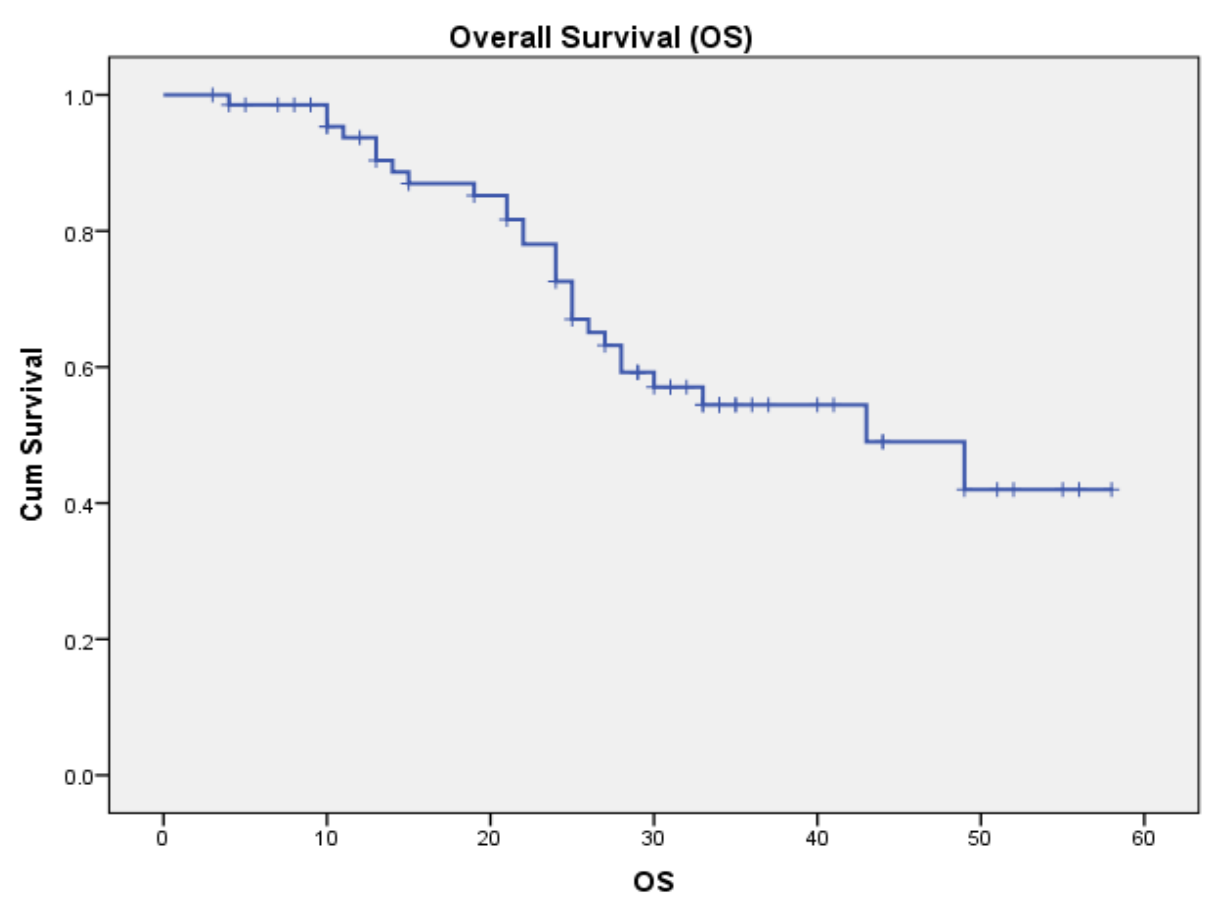

Figure 2: Overall survival 
Table 1: Patient and treatment variables

\begin{tabular}{|l|c|c|}
\hline Parameter & Variable & Number (\%) \\
\hline Age & Mean & 60 (range:32-82) \\
\hline Sex & Male & $53(76.8 \%)$ \\
& Female & $16(23.2 \%)$ \\
\hline T Stage & T2 & $2(2.9 \%)$ \\
& T3 & $31(44.9 \%)$ \\
& T4a & $33(47.8 \%)$ \\
& T4b & $3(4.3 \%)$ \\
\hline N stage & N0 & $43(62.3 \%)$ \\
& N1 & $20(29 \%)$ \\
& N2 & $6(8.7 \%)$ \\
\hline Length of disease & $\leq 6 \mathrm{~cm}$ & $46(66.7 \%)$ \\
& $>6 \mathrm{~cm}$ & $23(33.3 \%)$ \\
\hline Cycles of chemo & 0 & $7(10.1 \%)$ \\
& $1-3$ & $26(37.7 \%)$ \\
& $\geq 4$ & $36(52.2 \%)$ \\
\hline RT dose & $\leq 50.4 \mathrm{~Gy}$ & $59(85.5 \%)$ \\
& $60 \mathrm{~Gy}$ & $10(14.5 \%)$ \\
\hline
\end{tabular}

Table 2: Patterns of recurrence

\begin{tabular}{|l|c|c|}
\hline Parameter & Variable & Number(\%) \\
\hline Recurrence & Yes & $28(40.6 \%)$ \\
& No & $41(59.4 \%)$ \\
\hline Site of recurrence & Primary & $12(17.4 \%)$ \\
& Node (out of field) & $7(10.1 \%)$ \\
& Distant mets & $9(13.1 \%)$ \\
\hline Time to recurrence (All site) & $\leq 12 \mathrm{~m}$ & $11(39.2 \%)$ \\
Median: $17 \mathrm{~m}$ & $>12-24 \mathrm{~m}$ & $12(42.9 \%)$ \\
Range: $0-40 \mathrm{~m}$ & $>24 \mathrm{~m}$ & $5(17.9 \%)$ \\
\hline Time to recurrence (Primary) & $\leq 12 \mathrm{~m}$ & 4 \\
Median: $15.5 \mathrm{~m}$ & $>12-24 \mathrm{~m}$ & 7 \\
Range: $0-28 \mathrm{~m}$ & $>24 \mathrm{~m}$ & 1 \\
\hline Time to recurrence (Node) & $\leq 12 \mathrm{~m}$ & 3 \\
Median: $19.4 \mathrm{~m}$ & $>12-24 \mathrm{~m}$ & 2 \\
Range: $5-40 \mathrm{~m}$ & $>24 \mathrm{~m}$ & 2 \\
\hline Time to recurrence (Distant) & $\leq 12 \mathrm{~m}$ & 4 \\
Median: $15.2 \mathrm{~m}$ & $>12-24 \mathrm{~m}$ & 3 \\
Range: $3-27 \mathrm{~m}$ & $>24 \mathrm{~m}$ & 2 \\
\hline
\end{tabular}

Table 3: Univariate analysis - Disease free survival (DFS)

\begin{tabular}{|l|c|c|c|}
\hline Parameter & Variable & Median survival & P value \\
\hline Sex & Male & $38.0 \mathrm{~m}$ & 0.119 \\
& Female & $48.6 \mathrm{~m}$ & \\
\hline Age & $\leq 60 \mathrm{yrs}$ & $38.7 \mathrm{~m}$ & 0.501 \\
& $>60 \mathrm{yrs}$ & $43.2 \mathrm{~m}$ & \\
\hline T stage & $\mathrm{T} 2 / 3$ & $43.0 \mathrm{~m}$ & 0.508 \\
& $\mathrm{~T} 4$ & $35.3 \mathrm{~m}$ & \\
\hline N stage & $\mathrm{N} 0$ & $39.7 \mathrm{~m}$ & 0.373 \\
& $\mathrm{~N} 1 / 2$ & $42.7 \mathrm{~m}$ & \\
\hline Length of disease & $\leq 6 \mathrm{~cm}$ & $43 \mathrm{~m}$ & 0.227 \\
& $>6 \mathrm{~cm}$ & $36 \mathrm{~m}$ & \\
\hline RT dose & $50-50.4 \mathrm{~Gy}$ & $41 \mathrm{~m}$ & 0.979 \\
& $60 \mathrm{~Gy}$ & $30 \mathrm{~m}$ & \\
\hline Chemotherapy & Upto 3 cycles & $37.0 \mathrm{~m}$ & 0.492 \\
& $\geq 4$ cycles & $43.9 \mathrm{~m}$ & \\
\hline
\end{tabular}


Table 4: Univariate analysis - Overall survival (OS)

\begin{tabular}{|l|c|c|c|}
\hline Parameter & Variable & Median survival & P value \\
\hline Sex & Male & $40.2 \mathrm{~m}$ & 0.270 \\
& Female & $47.9 \mathrm{~m}$ & \\
\hline Age & $\leq 60$ yrs & $41.3 \mathrm{~m}$ & 0.927 \\
& $>60$ yrs & $43.7 \mathrm{~m}$ & \\
\hline T stage & $\mathrm{T} 2 / 3$ & $42.7 \mathrm{~m}$ & 0.961 \\
& $\mathrm{~T} 4$ & $37.9 \mathrm{~m}$ & \\
\hline N stage & $\mathrm{N} 0$ & $40.7 \mathrm{~m}$ & 0.337 \\
& $\mathrm{~N} 1 / 2$ & $45 \mathrm{~m}$ & 0.790 \\
\hline Length of & $\leq 6 \mathrm{~cm}$ & $41.9 \mathrm{~m}$ & 0.373 \\
disease & $>6 \mathrm{~cm}$ & $42.4 \mathrm{~m}$ & 0.347 \\
\hline RT dose & $50-50.4 \mathrm{~Gy}$ & $42 \mathrm{~m}$ & \\
& 60 Gy & $31.5 \mathrm{~m}$ & $38 \mathrm{~m}$ \\
\hline Chemotherapy & Upto 3 cycles & $47 \mathrm{~m}$ & \\
& $\geq 4$ cycles & &
\end{tabular}

\section{Discussion}

RTOG 85-01 demonstrated the superiority of concurrent chemoradiation over radiotherapy alone in the treatment of locally advanced esophageal carcinoma ${ }^{(8)}$. For patients with squamous cell carcinoma, cT1-3 N0-1 M0, combined therapy resulted in 3 year survival of $30 \%$ and a 5 year survival of $21 \%$. As the locoregional failure was still very high (46\%), attempts were made to improve local control by radiation dose escalation as well as by adding neoadjuvant chemotherapy. The phase II INT 0122 trial however had high treatment related mortality and was therefore closed ${ }^{(9)}$. The RTOG 95-01 trial evaluated the benefit of higher dose radiation, with 4 cycles of chemotherapy as in RTOG 85-01. Although the loco-regional failure, persistence of disease and distant metastasis were lower in the high dose arm, it was not statistically significant. As there was no increase in survival and locoregional control, the standard of treatment was accepted as concurrent chemoradiation with 50.4 Gy of radiation ${ }^{(10)}$.

Neoadjuvant chemotherapy followed by surgery following the publication of CROSS trial is considered the standard of care in the surgical management of carcinoma esophagus. In highly selected patients with T1N1 or T2-3N0-1M0, length of lesion less than $8 \mathrm{~cm}$ and weight-loss less than $10 \%$ over baseline, a 3 year survival of $58 \%$ was achieved, compared to $44 \%$ for surgery alone group $^{(11,12)}$. However caution needs to be exercised when extending its indication to patients with less optimal risk profile ${ }^{(13)}$. In the CROSS study, $49 \%$ of patients with squamous cell carcinoma attained pathological complete response with neoadjuvant chemoradiation, and the benefit of surgery in this group is questionable (11). In the French FFCD 9102 trial which had predominantly squamous cell carcinoma, $58 \%$ of the 444 patients who responded to initial chemoradiation were randomised to surgery of further chemoradiation. There was no benefit for the addition of surgery, the 2 year survival rate being $34 \%$ in the surgical arm compared to $40 \%$ in the non-surgical $\operatorname{arm}^{(7)}$. In the other randomized trial by the German group, there was no difference in survival at 2 years $(39.9 \%$ in surgical arm, $35.4 \%$ in the non-surgical arm) ${ }^{(6)}$. In both these trial, additional surgery resulted in higher local control rates and DFS, at the cost of higher postoperative mortality. Following these studies and the RTOG 0246, in some centres surgery is reserved for patients with residual or recurrent disease $^{(2,14)}$.

Here we present the results of radical chemoradiation in locally advanced squamous cell carcinoma of esophagus. Outside a clinical trial, there are very few reports of radical chemoradiation with platinum and 5FU, especially from a hospital based cohort. Majority of the patients had locally advanced disease with $\geq \mathrm{T} 3$ primaries (T3: 45\%, T4:52\%) and had a mean length of $5.75 \mathrm{~cm}$. Whereas in the RTOG $85-01$, 
only $8 \%$ had $\mathrm{T} 3$ disease and none had T4 disease and RTOG 94-05 had $\mathrm{T} 3$ in 34\% and $\mathrm{T} 4$ in $9 \%^{(10,15)}$. In the CROSS trial, while none had T4 stage, $84 \%$ had T3 disease with a mean length of $4 \mathrm{~cm}^{(12)}$. The compliance to treatment was good, with all patients completing the radiotherapy schedule and $52 \%$ receiving the full dose of chemotherapy. Only $10 \%$ did not receive chemotherapy.

We report a 2 and 3 year overall survival of $72.6 \%$ and $54.4 \%$ respectively. The RTOG $85-01$ result show a 2 and 3 year survivals of $38 \%$ and $30 \%$ respectively and for RTOG 94-05 the 2 year survival was $40 \%$ in the standard $\operatorname{arm}^{(10,16)}$. Another study from India done on locally advanced carcinoma esophagus reported 2 and 3 year survivals of $47 \%$ and $39 \%$ respectively ${ }^{(17)}$. Our results are among the best published studies on radical chemoradiation. High compliance to treatment both radiation and chemotherapy and inclusion of patients with squamous cell carcinoma only may have contributed to the same. Various parameters tested for its prognostic significance on DFS or OS were however not significant statistically, probably due to low patient numbers.

Forty-two percent of the recurrence $(17 \%$ of patients) occurred at site of primary itself, attesting to well established pattern of high local failure rates. Distant metastasis formed $32 \%$ of the recurrence (13\% of patients). In the INT 0123 standard arm, $46 \%$ patients had local failure or persistent disease, while $16 \%$ patients developed distant metastasis ${ }^{(9)}$. In another study on the patterns of recurrence after chemoradiation, $41 \%$ of patients developed local recurrence, which formed $86 \%$ of total failures ${ }^{(18)}$. A higher local control might have lead to more patients presenting later on with out of field nodal recurrence and distant metastasis. Most of the recurrence occurred within the first 2 years. Ninety two percent of local recurrence, $71 \%$ and $78 \%$ of nodal recurrence and distant metastasis respectively, occurred within this period. In 2 patients, isolated out of field nodal recurrence occurred after more than 24 months. Upper right para-esophageal lymph node, close to the level of clavicular head, was a common site for nodal recurrence especially in carcinomas of the middle thoracic esophagus.

\section{Limitations of the study}

Being retrospective in nature, all inherent deficiencies in data collection is acknowledged, especially with regards to acute toxicity, dose of chemotherapy given, and incomplete follow up of patients. All patients with suspected/documented recurrence were taken as expired on the day of last hospital visit to minimise the effect of censoring in survival analysis. Since endoscopic ultrasound was not available during the study period, this was not used for staging purpose, nor was PET-CT done as a standard investigation.

The study is still relevant as it provides information in the real-life setting ${ }^{(19)}$. The survival results reported are encouraging. There are scope for improvement in the staging evaluation, using endoscopic ultrasound and PET-CT ${ }^{(20,21)}$. Routine use of Intensity modulated radiotherapy has the potential to further reduce the toxicity, dose escalation and improve survival ${ }^{(22-24)}$.

\section{Conclusion}

Radical chemoradiation for squamous cell carcinoma of esophagus is feasible in the real-life setting and provides a good 3 year overall survival of $54 \%$. Loco-regional recurrence is the most common site for failure. More accurate staging of disease with endoscopic ultrasound and PET-CT, more sophisticated radiation with potential to reduce organ toxicity and dose-escalation, and reliable assessment of response to treatment with PET-CT and endoscopic ultrasound with early salvage treatment has the potential to improve these survival figures.

\section{Bibliography}

1. Ferlay J, Soerjomataram I, Ervik M, Dikshit R, Eser S, Mathers C, Rebelo M, Parkin DM, Forman D, Bray F. 
GLOBOCAN 2012 v1.0, Cancer Incidence and Mortality Worldwide: IARC CancerBase No. 11 [Internet]. Lyon, France: International Agency for Research on Cancer. 2013 [cited 2018 Jan 17]. Available from: http://globocan.iarc.fr/

2. Barbetta A, Hsu M, Tan KS, Stefanova D, Herman K, Adusumilli PS, et al. Definitive chemoradiotherapy versus neoadjuvant chemoradiotherapy followed by surgery for stage II to III esophageal squamous cell carcinoma. J Thorac Cardiovasc Surg [Internet]. 2018 Feb 15 [cited 2018 Mar 26]; Available from: http://linkinghub.elsevier.com/retrieve/pii/ S0022522318303702

3. Naik KB, Liu Y, Goodman M, Gillespie TW, Pickens A, Force SD, et al. Concurrent chemoradiotherapy with or without surgery for patients with resectable esophageal cancer: An analysis of the National Cancer Data Base. Cancer [Internet]. 2017 Sep 15 [cited 2018 Mar 26];123(18):3476-85. Available from: http://www.ncbi.nlm.nih.gov/pubmed/284 64264

4. Yen Y-C, Chang J-H, Lin W-C, Chiou J-F, Chang Y-C, Chang C-L, et al. Effectiveness of esophagectomy in patients with thoracic esophageal squamous cell carcinoma receiving definitive radiotherapy or concurrent chemoradiotherapy through intensity-modulated radiation therapy techniques. Cancer [Internet]. 2017 Jun 1 [cited 2018 Mar 26];123 (11):2043-53. Available from: http://www.ncbi.nlm.nih.gov/pubmed/281 52166

5. Vellayappan BA, Soon $\mathrm{YY}, \mathrm{Ku}$ GY, Leong CN, Lu JJ, Tey JCS. Chemoradiotherapy versus chemoradiotherapy plus surgery for esophageal cancer. Cochrane Database Syst Rev. 2013;2013(5).

6. Stahl M, Stuschke M, Lehmann N, Meyer H-J, Walz MK, Seeber S, et al.
Chemoradiation With and Without Surgery in Patients With Locally Advanced Squamous Cell Carcinoma of the Esophagus. J Clin Oncol [Internet]. 2005;23(10):2310-7. Available from: http://ascopubs.org/doi/10.1200/JCO.2005. 00.034

7. Bedenne L, Michel P, Bouch?? O, Milan C, Mariette C, Conroy $\mathrm{T}$, et al. Chemoradiation followed by surgery compared with chemoradiation alone in squamous cancer of the esophagus: FFCD 9102. J Clin Oncol. 2007;25(10):1160-8.

8. Cooper JS, Guo MD, Herskovic A, Macdonald JS, Martenson James A. J, AlSarraf M, et al. Chemoradiotherapy of Locally Advanced Esophageal Cancer. JAMA [Internet]. 1999 May 5;281(17):1623-7. Available from: http://jama.jamanetwork.com/article.aspx? doi=10.1001/jama.281.17.1623

9. Minsky BD, Neuberg D, Kelsen DP, Pisansky TM, Ginsberg R, Benson A. Neoadjuvant chemotherapy plus concurrent chemotherapy and high-dose radiation for squamous cell carcinoma of the esophagus: A preliminary analysis of the phase II intergroup trial 0122. J Clin Oncol [Internet]. 1996 Jan [cited 2018 Apr 2];14(1):149-55. Available from: http://ascopubs.org/doi/10.1200/JCO.1996. 14.1.149

10. Minsky BD, Pajak TF, Ginsberg RJ, Pisansky TM, Martenson J, Komaki R, et al. INT 0123 (Radiation Therapy Oncology Group 94-05) Phase III Trial of Combined-Modality Therapy for Esophageal Cancer: High-Dose Versus Standard-Dose Radiation Therapy. J Clin Oncol [Internet]. 2002 Mar [cited 2018 Mar 14];20(5):1167-74. Available from: http://ascopubs.org/doi/10.1200/JCO.2002. 20.5.1167

11. van Hagen $P$, Hulshof MCCM, van Lanschot JJB, Steyerberg EW, 
Henegouwen MI van B, Wijnhoven BPL, et al. Preoperative Chemoradiotherapy for Esophageal or Junctional Cancer. N Engl J Med [Internet]. 2012;366(22):2074-84. Available from: http://www.nejm.org/doi/10.1056/NEJMoa 1112088

12. Shapiro J, Lanschot JJB Van, Hulshof MCCM, Hagen $P$ Van, Henegouwen MIVB, Wijnhoven BPL. Neoadjuvant chemoradiotherapy plus surgery versus surgery alone for oesophageal or junctional cancer ( CROSS ): long-term results of a randomised controlled trial. Lancet Oncol [Internet]. 2015;16(9):10908. Available from: http://dx.doi.org/10.1016/S14702045(15)00040-6

13. Wong I, Law S. The CROSS road in neoadjuvant therapy for esophageal cancer: long-term results of CROSS trial. Transl Cancer Res [Internet]. 2016 [cited 2018 Apr 2];3(5):S415-9. Available from: http://tcr.amegroups.com/article/view/9247 /html

14. Castoro C, Scarpa M, Cagol M, Alfieri R, Ruol A, Cavallin F, et al. Complete clinical response after neoadjuvant chemoradiotherapy for squamous cell cancer of the thoracic oesophagus: is surgery always necessary? J Gastrointest Surg [Internet]. 2013 Aug 25 [cited 2018 Apr 2];17(8):1375-81. Available from: http://link.springer.com/10.1007/s11605013-2269-3

15. Herskovic A, Martz K, Al-Sarraf M, Leichman L, Brindle J, Vaitkevicius V, et al. Combined Chemotherapy and Radiotherapy Compared with Radiotherapy Alone in Patients with Cancer of the Esophagus. N Engl J Med [Internet]. 1992 Jun 11;326(24):1593-8. Available from: http://www.nejm.org/doi/abs/10.1056/NEJ M199206113262403
16. Cooper JS, Guo MD, Herskovic A, Macdonald JS, Martenson JA, Byhardt R, et al. Chemoradiotherapy of Locally Advanced. 1999;281(17):1623-7.

17. Noronha V, Prabhash K, Joshi A, Patil VM, Talole S, Nakti D, et al. Clinical Outcome in Definitive Concurrent Chemoradiation With Weekly Paclitaxel and Carboplatin for Locally Advanced Esophageal and Junctional Cancer. Oncol Res Featur Preclin Clin Cancer Ther [Internet]. 2016;23(4):183-95. Available from:

http://www.ingentaconnect.com/content/10 .3727/096504016X14537290676865

18. Versteijne E, van Laarhoven HWM, van Hooft JE, van Os RM, Geijsen ED, van Berge Henegouwen MI, et al. Definitive chemoradiation for patients with inoperable and/or unresectable esophageal cancer: locoregional recurrence pattern. Dis Esophagus. 2015;28(5):453-9.

19. Cohen AT, Goto S, Schreiber K, TorpPedersen C. Why do we need observational studies of everyday patients in the real-life setting? Eur Hear Journal, Suppl. 2015;17(April):D2-8.

20. Lowe VJ, Booya F, Fletcher JG, Nathan M, Jensen E, Mullan B, et al. Comparison of Positron Emission Tomography, Computed Tomography, and Endoscopic Ultrasound in the Initial Staging of Patients with Esophageal Cancer. Mol Imaging Biol [Internet]. 2005 Nov 4 [cited 2018 Apr 9];7(6):422-30. Available from: http://www.ncbi.nlm.nih.gov/pubmed/162 70235

21. Schreurs LMA, Janssens ACJW, Groen H, Fockens P, van Dullemen HM, van Berge Henegouwen MI, et al. Value of EUS in Determining Curative Resectability in Reference to CT and FDG-PET: The Optimal Sequence in Preoperative Staging of Esophageal Cancer? Ann Surg Oncol [Internet]. 2016 Dec 6 [cited 2018 Apr 
9];23(S5):1021-8. Available from:

http://www.ncbi.nlm.nih.gov/pubmed/215

47703

22. Freilich J, Hoffe SE, Almhanna K, Dinwoodie W, Yue B, Fulp W, et al. Comparative outcomes for threedimensional conformal versus intensitymodulated radiation therapy for esophageal cancer. Dis Esophagus [Internet]. 2015 May 1 [cited 2018 Apr 13];28(4):352-7. Available from: https://academic.oup.com/dote/articlelookup/doi/10.1111/dote.12203

23. Xu D, Li G, Li H, Jia F. Comparison of IMRT versus 3D-CRT in the treatment of esophagus cancer. Med (United States). 2017;96(31):1-7.

24. Haefner MF, Lang K, Verma V, Koerber SA, Uhlmann L, Debus J, et al. Intensitymodulated versus 3-dimensional conformal radiotherapy in the definitive treatment of esophageal cancer: Comparison of outcomes and acute toxicity. Radiat Oncol. 2017;12(1):1-7. 